\title{
KETOGENIC DIET FOR WEIGHT LOSS AND ITS IMPLICATION ON HEALTH: A LITERATURE STUDY
}

\author{
Rian Diana ${ }^{*}$, Dominikus Raditya Atmaka ${ }^{2}$ \\ ${ }^{1,2}$ Health Nutrition Department, Faculty of Public Health, Universitas Airlangga, Indonesia \\ *E-mail: rian.diana@fkm.unair.ac.id
}

\begin{abstract}
The prevalence of obesity has increased significantly and it has become a public health problem globally. Many strategies were done to overcome obesity. One of them is dietary approach. The popular and widely used weight loss diet is the ketogenic diet. This literature review aimed to discuss the mechanism of ketogenic diet in weight lost as well as its long and short term effects on health. Ketogenic diet is a very low-carbohydrate and high-fat diet. This diet restricts the carbohydrate intake up to 50 gram per day. The diet effective for losing weight in short term $(<6$ months), after 6 months there was no significant differences compared to other wight-loss diet. Study shows ketogenic diet gives both beneficial and harmful effects in short and long term for ketogenic dieters. This diet is not applicable for anyone, thus people with chronic diseases should receive guidance from dietitian or clinician in implementing this diet. Ketogenic dieters are suggested to replace their carbohydrate intake with complex carbohydrate (whole food-not refined), reduce animal-based protein, increasing plant-based protein and polyunsaturated fat, water, fermented foods and beverages.
\end{abstract}

Keywords: ketogenic diet, low carbohydrate diet, obese, ketone, weight loss

\section{INTRODUCTION}

Obesit has became world health problem which the prevalence is increasing $(8,5 \%$ in 1999 becomes $13,1 \%$ in 2016 (WHO 2016). Obesity is the risk factor for various non communicable disease like hypertension, diabetes mellitus, cardiovascular disease, and cancer (Fruh, 2017). Many effort has been performed to decrease obesity prevalence, one of them is diet therapy. Nowadays many diet has been developed in society which is low carbohydrate, high protein diet, high fat diet, or calorie restriction diet (Kirkpatrick et al. 2019). Low carbohydrate diet is one kind of diet which broadly used to lose body weight (Oh and Uppaluri 2019). Diet that has been proven effective to reduce body weight quickly is very low carbohydrate and high fat, or namely ketogenic diet (Bueno et al., 2013; Kirkpatrick et al., 2019; Sumithran and Proietto, 2008).

Ketogenic diet is low carbohydrate diet, high fat, and enough protein with composition $5-10 \%$ carbohydrate, $55-60 \%$ fat, and $30-35 \%$ protein (Masood and Uppaluri, 2019). Very low carbohydrate diet limit carbohydrate intake to 50 gram/day. This diet increasingly known to the public because it is believe can lose weight quickly.

The used of ketogenic diet for epileptics has been extensively reviewed (Meira et al., 2019; Qi and Tester, 2019; Roehl and Sewak, 2017), but the use of ketogenic diet for weight loss and the short and long term effects of this diet still controversial. Therefore this literature study aims to discuss how ketogenic diet can reduce body weight and its short and long term effect on health.

\section{KETOGENIC DIET HISTORY}

Ketogenic diet is a term that shows dietary therapy with diet composition that results in ketogenic state in human metabolism. Ketogenic diet contain very low carbohydrates (20-50 gram per day), high fat, and enough protein. Macronutrient intake from ketogenic diet has 55$60 \%$ fat, $30-35 \%$ protein, and $5-10 \%$ carbohdrate composition (Oh and Uppaluri, 2019).

Ketogenic diet aims to force body to break down fat into energy sources. Very low carbohydrate intake force body to do glycogen synthesis and if it happen for long time then body will begin to exp erience ketosis. Body begin 
to increase production of ketones from fat as an alternative energy source to replace glucose. This condition causes weight loss due to continuous fat breakdown (Roehl and Sewak, 2017; Oh and Uppaluri, 2019).

Ketogenic diet was originally used as therapy for epilepsy patient both in children and adults. Then this diet develop its use for people with diabetes, cancer, cardiovascular disease, including for weight loss. Ketogenic diet is one of effective non pharmacological measures for intractable epilepsy since 1920 (Meira et al., 2019). Some literature shows that fasting is a therapy to reduce the symptoms of seizures in epilepsy sufferers. At the beginning of 5 th century BC, Hippocrates wrote that fasting was useful for controlling seizures (Caraballo and Vining, 2012).

In 1911, Guelpa and Marie, medical doctors from Paris noted the use of fasting as therapy for epilepsy. In 1921 Dr. Russel Wilder, a medical doctor in Mayo Clinic Minnesota formulated idea that high fat and very low carbohydrate diet can cause ketonemia (effect like fasting). Dr. Wilder build classic ketogenic diet concept consisting of ketogenic and antiketogenic component can be useful for epileps therapy (Meira et al., 2019; Caraballo and Vining, 2012; Roehl and Sewak 2017).

In 1925, pediatrician named dr. Peterman made improvements to ketogenic diet and determined minimum daily calorie requirement of $75 \%$ of nutritional adequacy rate for certain height and weight and protein as much as $1 \mathrm{~g} / \mathrm{kg}$ body weight (Caraballo and Vining 2012). Ketogenic diet consider adequate nutrient intake to avoid occurrence of malnutrition. Calculation of classic ketogenic diet until this day still the same as initial formulated composition b Mayo Clinic, which is 1 gram protein $/ \mathrm{kg}$ body weight, $10-15$ gram carbohydrate, and remaining calories come from fat (Roehl and Sewak, 2017).

Ketogenic diet is currently used for weight loss (Kirkpatrick et al., 2019), diet therapy for cancer (Weber et al., 2019), mitochondrial dysfunction (Hasan-Olive et al., 2019), alzheimer (Rusek et al., 2019), inflammation, oxidative stress (Pinto et al., 2018), and movement disorders and severe or traumatic brain injury (McDougall et al., 2018).
Table 1. Diet Type Based on Carbohydrate Proportion to Total Energy

\begin{tabular}{lcc}
\hline \multicolumn{1}{c}{ Diet } & Ketogenic & $\begin{array}{c}\text { Proportion Carbohydrate } \\
\text { to total energy }\end{array}$ \\
\hline $\begin{array}{l}\text { High } \\
\text { carbohydrate }\end{array}$ & No & $\begin{array}{c}45-65 \% \text { total energy } \\
(169-244 \text { gram/day })\end{array}$ \\
$\begin{array}{l}\text { Enough } \\
\text { carbohydrate }\end{array}$ & No & $\begin{array}{c}26-44 \% \text { total energy } \\
(130-225 \text { gram } / \text { day })\end{array}$ \\
Low & & $10-25 \%$ total energy \\
carbohydrate & No & $(50-130$ gram $/$ day $)$ \\
Very low & & $<10 \%$ total energy* \\
carbohydrate & Yes & $(<50$ gram/day $)$ \\
\hline
\end{tabular}

Note: *Based on $2000 \mathrm{kcal}$ diet per day, and the amount of carbohydrate needed to stimulate ketosis in most adults

Ketogenic diet began to be considered as diet for weight loss after development of low carbohydrate diet, such as Atkins diet. In 1970, Robert Atkins developed diet to lose weight by limiting carbohydrate intake (Atkins diet), then this diet was also used for seizure therap in people with epilepsy (Modified Atkins Diet) (Meira, et al. 2019).

Since 1972 low carbohydrate diet has been used as one strategy for weight loss. Currently, attention to low carbohydrate diets continues to grow, including ketogenic diet. All low carbohydrate diets in principle reduce overall carbohydrate intake, but there is no consensus on the definition of low carbohydrate diet (Oh and Uppaluri, 2019). Carbohydrate restrition diet is a diet with carbohydrate intake below the range of carbohydrate intake the is acceptable for healthy adults (45-65\% total energy). Carbohydrate restriction diet can be divided into 4 category as shown in table 1 (Kirkpatrick et al., 2019; Oh and Uppaluri, 2019).

\section{KETONE BODY METABOLISM}

There are 3 types of ketone bodies produced by body, namely acetoacetate, $\beta$-hydroxybutyrate, and acetone. Acetoacetate is the main ketone body produced, then acetoacetate will be converted into ß-hydroxybutyrate, and acetone (Kirkpatrick et al., 2019). A healthy adult has $2-6 \%$ ketone supply frpm body energy needs after a day of fasting and reaches $30 \%-40 \%$ of energy needs after 3 days of fasting (Sumithran and Proietto, 2008). Measurement of ketone body concentrations can 


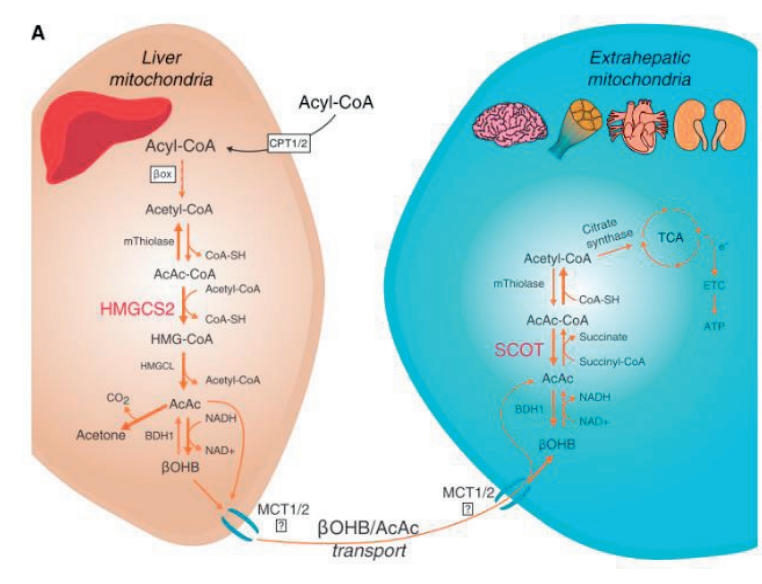

Figure 1. Ketone Bodies Metabolism.

Source: (Puchalska and Crawford, 2017)

be done in blood serum (ß-hydroxybutyrate), urine (acetoacetate), and breath (acetone) (Roehl and Sewak, 2017).

Under normal circumstances, glucose is body main energy source through three mecanism, that is glycolisis, Krebs cycle or Trycarboxylic Acid cycle (TCA cycle) and the electron transport chain (ETC) (Puchalska and Crawford, 2017). When enough carbohydrate intak, insulin will stimulate lipogenesis and suppress production of ketone bodies. Therefore ketone body concentration is very low $(<0,3 \mathrm{mmol} / \mathrm{L})$ compared to glucose $(4 \mathrm{mmol} / \mathrm{L})$. After a few days of carbohydrate intake reduction (a very low carbohydrate diet) the production of blood glucose from gluconeogenesis become inadequate and central nervous system needs additional energy sources. During carbohydrate intake restrictions, insulin level will decrease meanwhile glucagon will increase. This condition will result in decreasing lipogenesis and increasing oxidation of fatty acid in the liver. Increased fatty acid oxidation will cause excess production of acetyl-CoA as a result liver cell mitochondria will produce ketone bodies (Kirkpatrick et al., 2019). In a state of low blood glucose, gluconeogenesis will occur and body will start using second energy source, that is fatty acids. Brain use glucose as energy source and cannot be replaced by fatty acid because fatty acid cannot pass through blood brain barrier. Therefore, fatty acid must first converted into ketone body so that they can pass blood brain (Puchalska and Crawford, 2017).
Ketone bodies can be alternative source of energy for the brain other than carbohydrates because ketone bodies have the same binding affinity (Michaelis-Menten or kM) as glucose. Central nervous system starts using the ketone body as an energy source when the plasma ketone body concentration is around $4 \mathrm{mmol} / \mathrm{L}$. Ketone bodies in healthy adults generally do not exceed 8 $\mathrm{mmol} / \mathrm{L}$ because central nervous system efficiently use them as energy source instead of glucose and can be toxic if the levels are excessive (Kirkpatrick et al., 2019).

Ketogenesis is ketone bodies forming process ( $\beta$-hydroxybutyrate, acetoacetate, acetone) mainly in liver cells mitochondria while ketolysis (breakdown of ketone bodies) occurs in muscle and brain cells (Gropper and Smith, 2013). When ketosis occurs, liver cell produce ketone bodies (acetacetate, acetone, and $\beta$-hydroxybutyrate) then ketone body is distributed to extrahepatic tissue (heart muscle, skeletal muscle, kidney, and brain). Ketone bodies breakdown in mitochondrial extrahepatic tissue into acetyl-CoA which can enter Krebs cycle to produce energy especially in hungry period (Gropper and Smith, 2013). Metabolic process of ketone bodies can be seen in Figure 1 .

Ketone body production is tightly regulated and depends on 3 main enzymes activity that is lipase sensitive hormone, acetyl-CoA carboxylase, and HMG CoA synthase (convert acetoacetyl CoA to HMG CoA) (Sumithran and Proietto, 2008). When ketogenesis occurs, blood glucose levels are still in normal levels due to the presence of gluconeogenesis from amino acids and glycerol (triglyceride hydrolysis). On day 3 and 4 of ketogenic diet, the main source of glucose formation is from amino acids through gluconeogensis. When ketogenic condition is maintained, contribution of amino acids will decrease and amount of glucose produced from glycerol will increase. Based on studies related to the effects of fasting and very low carbohydrate diet, metabolic adaptation to ketosis occurs around two weeks or more until permanent ketone levels are reached (Kirkpatrick et al., 2019).

In general, ketosis occurs when serum ketones increase from $1 \mathrm{mmol} / \mathrm{L}$ to $7 \mathrm{mmol} / \mathrm{L}$ but do not produce acidic metabolic substances, in other words, it does not occur until ketoacidosis $(\mathrm{Oh}$ 
and Uppaluri, 2019). Ketogenic diet in weight loss generally produces serum ketones from 0.33 to $0.72 \mathrm{mmol} / \mathrm{L}$, whereas in diabetes ketoacidosis it is around $25 \mathrm{mmol} / \mathrm{L}$. While hyperketonemia and ketoacidosis occur if blood serum acetoacetate levels $>0.2 \mathrm{mmol} / \mathrm{L}$ and $\beta$-hydroxybutyrate $>7 \mathrm{mmol} / \mathrm{L}$ (Puchalska and Crawford, 2017; Sumithran and Proietto, 2008).

Acetoacetate and B-hydroxybutyrate are two ketone bodies which are used as fuel when lack of carbohydrate (low carbohydrate) in body occurs (Sumithran and Proietto, 2008). Acetoacetate has pKA 3.6 and $\beta$-hydroxybutyrate has pKA 4.7. Both ketone bodies can donate proton to blood vessel which can cause acidosis or ketoacidosis (Puchalska and Crawford, 2017). Acetone is formed as a result of acetoacetate decarboxylation, has volatile characteristics, and is released through respiratory tract giving smell of ketones in breath of people who have ketosis (Sumithran and Proietto, 2008).

When ketone body is too much it will cause acetone smelling breath, high anion gap, disruption of body acid-base balance (Gropper and Smith, 2013), acidosis, and will also stimulate part of brain called postrema area and trigger excessive vomiting, dehydration until the most severe stage, which is coma (Puchalska and Crawford, 2017).

\section{KETOGENIC DIET FOR WEIGHT LOSS}

Composition of macro nutrients in diet is an important determinant factor in ketosis. Consumption of carbohydrates mainly comes from non-starchy vegetables or fruits with low carbohydrate content (Abbasi, 2018). A very strict ketogenic diet with 4: 1 or 3:1 fat and carbohydrate ratio has low palatabillity making it difficult to do for long period. Meanwhile, ketogenic diet with ratio of 2: 1 and 1: 1 or modified Atkins diet has better palatability (Meira et al., 2019). Comparison of ketogenic diet with balance nutrition guideline can be seen in table 2 .

Low carbohydrate and high protein diet do not cause ketosis because 100 gram protein from food can produce 57 gram glucose. Ketogenic diet which usually used in epilepsy therapy in children limits protein and carbohydrates with fat to carbohydrate and protein ratio $3: 1$ or $4: 1$ ).
Table 2. Comparison of Macro Nutritional Composition in Ketogenic Diet with Balanced Nutrition Guidelines

\begin{tabular}{lccc}
\hline \multicolumn{1}{c}{ Diet } & Carbohydrate & Fat & Protein \\
\hline $\begin{array}{l}\text { Balance Nutrition } \\
\text { Guideline }^{1}\end{array}$ & $55-65 \%$ & $25-35 \%$ & $10-15 \%$ \\
Ketogenic Diet Ratio $^{2}$ & & & \\
$4: 1$ & $2-4 \%$ & $90 \%$ & $6-8 \%$ \\
$3: 1$ & $2-5 \%$ & $85-90 \%$ & $8-12 \%$ \\
$2: 1$ & $5-10 \%$ & $80-85 \%$ & $10-15 \%$ \\
Atkin Diet & $20-30 \%$ & $60-70 \%$ & $25-35 \%$ \\
Modification $^{2}$ & & & \\
\hline
\end{tabular}

Source : ${ }^{1}$ Kemenkes RI, 2014); ${ }^{2}$ (Roehl and Sewak, 2017)

Ketosis will occur if fat intake more than twice intake of carbohydrates plus half protein intake of fat intake (Sumithran and Proietto, 2008).

To reach the state of ketosis, it is necessary to formulate ketogenic diet properly because fat intake and total energy are not limited. Besides very low carbohydrate intake, limiting protein intake also needs to be done. Protein intake is limited by pay attention to sufficient amount to maintain body mass (Abbasi, 2018).

The ketogenic diet limits carbohydrate and protein intake ( $<1$ gram per kg body weight) except for individual who have heavy exercise habit (1.5 grams per $\mathrm{kg}$ body weight). Carbohydrate and protein restriction is done to prevent endogenous glucose production through gluconeogenesis, but does not limit overall fat or energy intake (Masood and Uppaluri, 2019).

In a state of ketosis, a reduction in overall calory intake can increase weight loss (Masood and Uppaluri, 2019). Systematic review and meta analysis by Gibson et al. (2015) showed individuals who were on low-energy diet and ketogenic diet had decreased hunger (feeling fuller) (Gibson et al., 2015). Decreasing hunger naturally can reduce overall calorie intake and lose weight (Abbasi, 2018).

Ketogenic diet significantly influences energy intake and expenditure. Some studies show that replacement of carbohydrate with fat result in greater energy expenditure. This condition is due to changes in levels of catecholamines and thyroid hormones that affect energy expenditure 
of individual on ketogenic diet, although the mechanism is not fully understood (Kirkpatrick et al. 2019).

Table 3 shows results and discussion of weight changes with ketogenic diet. On the ketogenic diet, weight loss occurs significantly compared to a low fat diet, especially in the first 3-6 months. However, if compared with balanced nutritional diet and ketogenic diet $>6$ months, the difference is not significant.

Results of 11 studies review conducted by Sumitharan and Proietto (2008) showed that ketogenic diet carried out for 3-6 months can lose weight higher than low fat diet. However, the difference in weight loss was not significantly different after 12 months.

In short term ( $\leq 6$ months), low calorie ketogenic diet has higher weight loss compared to other low calorie diets such as high carbohydrate and low fat diet. But in the long period ( $>6$ months), weight loss between two diets is same. Very low carbohydrate diet (including ketogenic diet) are difficult to maintain in long period and are no better than diet with higher carbohydrate intake (Kirkpatrick et al., 2019).

There are several alleged mechanisn of ketonic diet ini losing body weight:

1. Ketogenic diet give diuretic effect. Weight loss happen at the beginning of diet due to diuretics or water expenditure followed by fat loss (Masood and Uppaluri, 2019; Sumithran and Proietto, 2008). Each gram of glycogen stores in liver and muscle contain about 2 gram of water. Deposits of glycogen in liver around 100 gram and in muscle around 400 gram. Decreased glycogen reserves and ketonuria increase sodium levels in kidneys and water excretion. (Sumithran and Proietto, 2008).

2. Next weight loss occur because body begin to burn fat stored in adipose tissue, then weight loss can continue (Abbasi, 2018).

Table 3. Ketogenic diet weight loss from various research results

\begin{tabular}{|c|c|c|c|c|}
\hline \multirow[b]{2}{*}{ No. } & \multirow[b]{2}{*}{ Diet Period } & \multicolumn{2}{|c|}{ Body Changes Reduction } & \multirow[b]{2}{*}{ Note } \\
\hline & & Ketogenic Diet & $\begin{array}{c}\text { Non Ketogenic } \\
\text { Diet }\end{array}$ & \\
\hline $\begin{array}{l}\text { 1. Experimental study giving } \\
\text { ketogenic diet intervention to } \\
35 \text { obese adult (Mohorko et al. } \\
\text { 2019) }\end{array}$ & 3 months & $\begin{array}{l}\text { Male } 18 \pm 9 \mathrm{~kg} \\
\text { Female } 11 \pm 3 \mathrm{~kg}\end{array}$ & - & $\begin{array}{l}\text { Significant body weight reduction } \\
\text { with average } 11-18 \mathrm{~kg}\end{array}$ \\
\hline $\begin{array}{l}\text { 2. Clinical trial giving ketogenic } \\
\text { diet to } 20 \text { obese adult (Gomez- } \\
\text { Arbelaez et al. } 2017 \text { ) }\end{array}$ & 4 months & $20.2 \pm 4.5 \mathrm{~kg}$ & - & $\begin{array}{l}\text { Significant body weight reduction } \\
\text { with average } 20 \mathrm{~kg} \text {, muscle mass } \\
\text { reduction } 16,5 \mathrm{~kg}\end{array}$ \\
\hline $\begin{array}{l}\text { 3. Meta analysis from } 11 \\
\text { Randomised Control Trial (RCT) } \\
\text { (Mansoor et al. 2016) }\end{array}$ & 6-24 months & $2.9 \mathrm{~kg}-14.5 \mathrm{~kg}$ & $1.8 \mathrm{~kg}-11.5 \mathrm{~kg}$ & $\begin{array}{l}\text { Ketogenic diet has } 2,2 \mathrm{~kg} \text { body } \\
\text { weight reduction higher than low } \\
\text { fat diet group }\end{array}$ \\
\hline $\begin{array}{l}\text { 4. Ketogenic diet study in } 75 \\
\text { people compare with low fat diet } \\
\text { Randomized Control Trial (Hu et } \\
\text { al., 2015) }\end{array}$ & 3-12 months & $3.8 \mathrm{~kg}-6.8 \mathrm{~kg}$ & $0.3 \mathrm{~kg}-3.3 \mathrm{~kg}$ & $\begin{array}{l}\text { Ketogenic diet give body fat } \\
\text { reduction effect higher than } 3,5 \\
\text { kg compare with low fat diet }\end{array}$ \\
\hline $\begin{array}{l}\text { 5. Ketogenic diet study in } 9 \text { male } \\
\text { compare with low fat diet } \\
\text { Randomized Control Trial } \\
\text { (Vargas et al., 2018) }\end{array}$ & 8 weeks & $1.4 \mathrm{~kg} \pm 0.1 \mathrm{~kg}$ & $+0.9 \mathrm{~kg} \pm 0.4 \mathrm{~kg}$ & $\begin{array}{l}\text { Ketogenic diet can decrease body } \\
\text { weight } 1,4 \mathrm{~kg} \text { in } 8 \text { weeks while } \\
\text { low fat diet increase body weight }\end{array}$ \\
\hline $\begin{array}{l}\text { 6. Meta analysis from } 13 \\
\text { Randomised Control Trial (RCT) } \\
\text { (Bueno et al. 2013) }\end{array}$ & $12-24$ months & $1.5 \mathrm{~kg}-13.1 \mathrm{~kg}$ & $0.2 \mathrm{~kg}-11.6 \mathrm{~kg}$ & $\begin{array}{l}\text { Ketogenic diet can decrease body } \\
\text { weight } 0,9 \mathrm{~kg} \text { higher than low fat } \\
\text { diet group }\end{array}$ \\
\hline $\begin{array}{l}\text { 7. Meta analysis from } 19 \mathrm{RCT} \\
\text { (Naude et al. 2014) }\end{array}$ & $\begin{array}{l}3-6 \text { months } \\
1-2 \text { years }\end{array}$ & $2.65 \mathrm{~kg}-10.2 \mathrm{~kg}$ & $3.5 \mathrm{~kg}-10.9 \mathrm{~kg}$ & $\begin{array}{l}\text { Ketogenic diet can decrease body } \\
\text { weight as much as in balance } \\
\text { nutrient diet (not significant) }\end{array}$ \\
\hline $\begin{array}{l}\text { 8. Very low calory ketogenic diet } \\
\text { RCT study in } 27 \text { obese people } \\
\text { (Moreno et al., 2014) }\end{array}$ & $\begin{array}{l}2 \text { months } \\
12 \text { months }\end{array}$ & $13.6 \pm 3.9 \mathrm{~kg}$ & $4.8 \pm 2.7 \mathrm{~kg}$ & $\begin{array}{l}\text { Very low calory ketogenic diet can } \\
\text { decrease body weight } 2-3 \text { times } \\
\text { more than low calory diet }\end{array}$ \\
\hline
\end{tabular}


3. Ketones can suppress appetite. This decreased appetite can naturally reduce overall calorie intake which can reduce weight. Lowcarbohydrate ketogenic diets provide metabolic benefit by increasing gluconeogenesis (Abbasi, 2018; Sumithran and Proietto, 2008).

4. Limiting food choices, low palatability of low-carbohydrate diet, the satiating effect of relatively high protein and fat intake, increasing thermogenic effect of protein and fat, increasing lipolysis of fatty tissue due to reduced insulin levels, and increasing fatty acid oxidation (Sumithran and Proietto, 2008).

Effect of ketogenic diet on body composition cause decrease in total water content in body (ketosis is associated with total body water loss). This condition is being cause of weight loss at the beginning of ketogenic diet. Ketogenic dieter also experienced decrease in non-fat body mass that was higher than low-calorie diets with more balanced macro nutrients. Reduction in nonfat mass can be due to high protein content in ketogenic diet (Kirkpatrick et al., 2019).

Basically, carbohydrates are the main source of energy in body tissue. When body experiences carbohydrate deficiency due to low intake $(<50$ grams / day), insulin secretion will be drastically reduced and body will enter catabolic stage. Glycogen stores will decrease, forcing body to adapt to changes in energy metabolism. There are two metabolic processes that occur when availability of carbohydrates in body tissue decreases, that is gluconeogenesis and ketogenesis. Gluconeogenesis is endogenous production of glucose in liver. This glucose production comes from lactic acid, glycerol, and alanine and glutamine amino acid. When availability of glucose continues to decline and endogenous glucose production can no longer meet body needs, then ketogenesis is started to provide alternative source of energy in form of ketone bodies. Glucose is replaced by ketone bodies as main energy source (Masood and Uppaluri, 2019).

After few days of fasting (3-4 days) or a drastic reduction in carbohydrate intake $(<20$ grams per day), body glucose reserves become insufficient to produce oxaloacetate (for fat oxidation in Krebs cycle) and provide energy (glucose) for central nervous system (Paoli, 2014). Insulin secretion decreases and after one week, body start burning fat. This condition is called nutritional ketosis, so ketogenesis begin and energy sources switch to using ketone body (Abbasi, 2018).

Central nervous system cannot use fatty acid as energy source because fatty acid cannot pass through blood-brain barrier. Therefore central nervous system require another alternative source of energy, that is ketone body (which produced from acetyl Co-A). Liver produces ketone body, but liver and red blood cells cannot use it because there is no 3-ketoacyl CoA transferase enzyme needed to convert acetoacetate to acetacetyl-CoA (Paoli, 2014).

When ketogenesis occurs blood glucose become low. Therefore, insulin secretion become low, reducing glucose and fat storage stimuli. Other hormonal changes contribute to increase in breakdown of fat into fatty acids. Fatty acids are metabolized into acetate which then converted to $\beta$-hydroxybutyrate and acetone. This metabolic process results in accumulation of ketone bodies in body so that ketogenic diet can take place. As long as body is in state of carbohydrate deficiency, energy metabolism will continue to occur in state of ketosis. Condition of nutritional ketosis is considered safe because ketone body produced in small concentrations so that it cannot change blood $\mathrm{pH}$. This condition is very different from the condition of ketoacidosis, which is a lifethreatening condition due to production of ketone body so much that it changes blood $\mathrm{pH}$ become acidic (Masood and Uppaluri, 2019).

The results of meta-analysis show that low and very low carbohydrate diet (including ketogenic diet) is not superior compared to other diets with more carbohydrate intake. Study of Sacks et al. (2009) describe almost the same level of satisfaction in subjects given 4 types of lowcalorie diets (low fat-moderate protein, low-fathigh protein, high-fat-moderate protein, and highfat-high protein). Although there are differences in weight loss in each subject in each diet group. Some have very high or above average weight loss (Sacks et al., 2009). This explains food choices a person must consider in choosing a weight loss diet (Kirkpatrick et al., 2019). 


\section{SHORT TERM LONG TERM EFFECT OF KETOGENIC DIET TO HEALTH}

Health effects experienced by people on ketogenic diet can vary depending on tolerance and the amount of carbohydrate restrictions. Table 4 shows the short-term and long-term effects of ketogenic diet on health.

Short-term effects that are felt by many ketogenic dieters are experiencing symptom such as keto flu (dizziness, lightheadedness, weakness, fatigue, difficulty exercising, lack of sleep, and constipation) (Abbasi, 2018) and digestive tract problems such as nausea, vomiting, constipation and abdominal pain (Kirkpatrick et al. 2019). Besides dehydration, hypoglycemia, increased LDL cholesterol, and uric acid can also occur in ketogenic dieters (Kirkpatrick et al., 2019; Sumithran and Proietto 2008; Mansoor et al., 2016; Bueno et al., 2013).

Prospective cohort study conducted in USA on 15,428 adults aged $45-64$ years and a meta-analysis of 8 cohort studies showed low carbohydrate intake $(<40 \%$ total energy) and high carbohydrate $(>70 \%$ total energy) had a higher risk of death compared

Table 4. Short-Term and Long-Term Impact of Ketogenic Diet on Health

\begin{tabular}{ll}
\hline \multicolumn{1}{c}{ Effect } & \multicolumn{1}{c}{ Note } \\
\hline Short term ( $\leq \mathbf{6}$ months) & \\
1. Weight loss (Mohorko et al. 2019; Gomez-Arbelaez et al. & $\begin{array}{l}\text { Weight loss is significantly higher than other diets, especially in } \\
\text { subjects that are obese and overweight. }\end{array}$
\end{tabular}

2. Gastrointestinal problems such as nausea, vomiting, constipation, and stomach pain (Kirkpatrick et al. 2019)

3. Symptoms such as keto flu (dizziness, lightheadedness, weakness, fatigue, difficulty to exercise, lack of sleep, and constipation) (Abbasi 2018)

4. Headaches, skin rashes, muscle spasms, weakness, diarrhea, dehydration, hypoglycemia, increased uric acid in blood and vitamin and mineral deficiencies (Kirkpatrick et al. 2019; Sumithran and Proietto 2008).

Gastrointestinal problems are felt in the first week.

This complaint is felt after starting ketogenic diet 2-4 days and can last for several days to one week. This symptom is a form of body adaptation to the use of ketone bodies as an energy source. Consumption of protein from food can provide enough sodium, potassium and magnesium to reduce these symptoms.

Increased urine output can cause decreased electrolyte levels including sodium, magnesium and potassium which are associated with symptoms of hypovolemia and dizziness. People on the ketogenic diet should ensure adequate fluid and electrolyte intake.

5. Increased LDL kolesterol (Mansoor et al. 2016; Bueno et al. 2013)

6. Decreased Bifidobacteria, E. rectale, and Dialister also increased E. coli amount (Lindefeldt et al. 2019)

7. Decreased total stool mass, slower bowel movement, decreased intestinal fermentation, decreased stool SCFA levels, decreased intestinal health conditions, and increased risk of colon disease (Brinkworth et al., 2009)

\section{Long term ( $>6$ months)}

1. Vitamin and mineral deficiency (Sumithran and Proietto 2008).

2. Lipid profile such as triglyceride and HDL are not good (Kirkpatrick et al. 2019).

3. Increased cardiovascular disease risk (Manikam et al. 2018)

4. Increased non-alcoholic fatty liver disease and insulin resistance (Kosinski and Jornayvaz 2017)

This increase is thought to originate from a high intake of saturated fatty acids in ketogenic diet (Kirkpatrick et al. 2019).

Changes in composition of intestinal microbiota occur after 3 months of implementing ketogenic diet in epilepsy patients. Bacteria that play a role in consumption of complex carbohydrates are reduced. Diets high in polyunsaturated fats, vegetable protein, and consumption of fermented foods and drinks can maintain the normal function of microbiota (Paoli et al. 2019).

Decreased carbohydrate intake can interfere bowel movements and gut microbiota composition, especially Bifidobacteria. This results in decreased fermentation and decreased yield of SCFA metabolites which have a protective effect on colon disease (Brinkworth et al., 2009)

Adequacy of nutrients will depend on several factors such as carbohydrate restriction level, food sources of nutrient, and duration of diet.

Lipid profile is better in people on low-moderate carbohydrate diet compared to very low carbohydrate diet such as ketogenic diet.

High consumption of saturated fat can increase LDL cholesterol and decrease bronchial artery dilatation thereby increasing the risk of cardiovascular disease.

Study with animal. 
to people who consume carbohydrates between 50$55 \%$ of total energy. The risk of death will increase if carbohydrates are replaced with animal foods (goats, cows, chickens, pigs), and decreases if replaced with plant foods (vegetables, beans, whole cereals) (Seidelmann et al., 2018). Therefore, when someone is on carbohydrate restriction diet for weight loss, carbohydrate should be replaced with unsaturated fats or sources of fat and vegetable protein.

People who have chronic diseases such as diabetes mellitus, heart failure, kidney disease, liver disease and cancer if want to go on ketogenic diet should be under supervision of medical person and get nutritional therapy from registered dietesien. People with history of hypertriglyceride, acute pancreatic disease, and hypercholesterolaemia are not advised to go on ketogenic diet (Kirkpatrick et al., 2019).

\section{CONCLUSION}

Ketogenic diet is a very low carbohydrate diet that limits carbohydrate intake below $10 \%$ of total energy to stimulate ketosis in body. Ketogenic diet can lose weight quickly. Ketogenic diet can cause short-term complaints (keto flu, digestive problems, dehydration, hypoglycemia, elevated LDL, and uric acid) and long-term disease risk (deficiency of mineral vitamins, poor lipid profile, increase fatty liver disease).

Person perform ketogenic diet should replace carbohydrate intake with complex (whole) carbohydrate sources, reduce animal protein, increase vegetable protein, increase polyunsaturated fat and water consumption. To maintain weight it is recommended to make diet transition to a more balanced and more durable diet. Patients with hypertriglycerides, acute pancreas, and hypercholesterolemia are not allowed to go on a ketogenic diet.

\section{REFERENCES}

Abbasi, J. (2018). Interest in the Ketogenic Diet Grows for Weight Loss and Type 2 Diabetes. Jama, 319(3), 215-217. https://doi.org/10.1001/ jama.2017.20639

Brinkworth, G.D., Noakes, M., Clifton, P.M., Bird, A.R. (2009). Comparative Effects of
Very Low Carbohydrate, High Fat and High Carbohydrate, Low Fat Weight Loss Diets on Bowel Habit and Faecal Short Chain Fatty Acids and Bacterial Population. British Journal of Nutrition 101:1493-1502. https://doi.org/ S000711450894658

Bueno, N.B., De Melo, I.S.V., De Oliveira, S.L., \& Da Rocha Ataide, T. (2013). Very-lowcarbohydrate ketogenic diet v. low-fat diet for long-term weight loss: A meta-analysis of Randomised controlled trials. British Journal of Nutrition, 110(7), 1178-1187. https://doi. org/10.1017/S0007114513000548

Caraballo, R.H., \& Vining, E. (2012). Ketogenic diet. Handbook of Clinical Neurology (1st ed., Vol. 108). Elsevier B.V. https://doi.org/10.1016/ B978-0-444-52899-5.00027-7

Fruh, S.M. (2017). Obesity: Risk factors, complications, and strategies for sustainable long-term weight management. Journal of the American Association of Nurse Practitioners, 29, S3-S14. https://doi.org/10.1002/23276924.12510

Gibson, A.A., Seimon, R.V., Lee, C.M.Y., Ayre, J., Franklin, J., Markovic, T.P., ... Sainsbury, A. (2015). Do ketogenic diets really suppress appetite? A systematic review and metaanalysis. Obesity Reviews, 16(1), 64-76. https:// doi.org/10.1111/obr.12230

Gomez-Arbelaez, D., Bellido, D., Castro, A.I., Ordonez-Mayan, L., Carreira, J., Galban, C., ... Casanueva, F.F. (2017). Body composition changes after very-low-calorie ketogenic diet in obesity evaluated by 3 standardized methods. Journal of Clinical Endocrinology and Metabolism, 102(2), 488-498. https://doi. org/10.1210/jc.2016-2385

Gropper, S.S., \& Smith, J.L. (2013). Advanced Nutrion and Human Metabolism Sixth Edition (Sixth Edit). Belmont, USA: Wadsworth Cengage Learning.

Hasan-Olive, M.M., Lauritzen, K.H., Ali, M., Rasmussen, L.J., Storm-Mathisen, J., \& Bergersen, L.H. (2019). A Ketogenic Diet Improves Mitochondrial Biogenesis and Bioenergetics via the PGC1 $\alpha$-SIRT3-UCP2 Axis. Neurochemical Research, 44(1), 22-37. https://doi.org/10.1007/s11064-018-2588-6

Hu, T., Yao, L., Reynolds, K., Whelton, P.K., Niu, T., Li, S., He, J., Bazzano, L.A. (2015). The Effects of a Low-Carbohydrate Diet vs. a LowFat Diet on Novel Cardiovascular Risk Factors: A Randomized Controlled Trial. Nutrients 
2015, 7, 7978-7994. https://doi.org/10.3390/ nu7095377

Kementerian Kesehatan RI. (2014). Pedoman Gizi Seimbang. Jakarta: Kementerian Kesehatan RI.

Kirkpatrick, C.F., Bolick, J.P., Kris-Etherton, P.M., Sikand, G., Aspry, K.E., Soffer, D.E., ... Maki, K.C. (2019). Review of current evidence and clinical recommendations on the effects of low-carbohydrate and very-low-carbohydrate (including ketogenic) diets for the management of body weight and other cardiometabolic risk factors: A scientific statement from the Nati. Journal of Clinical Lipidology, (September), Article In Press. https://doi.org/10.1016/J. JACL.2019.08.003

Kosinski, C., \& Jornayvaz, F.R. (2017). Effects of ketogenic diets on cardiovascular risk factors: Evidence from animal and human studies. Nutrients, 9(5), 1-16. https://doi.org/10.3390/ nu9050517

Lindefeldt, M., Eng, A., Darban, H., Bjerkner, A., Zetterström, C.K., Allander, T., ... PrastNielsen, S. (2019). The ketogenic diet influences taxonomic and functional composition of the gut microbiota in children with severe epilepsy. Npj Biofilms and Microbiomes, 5(1). https://doi. org/10.1038/s41522-018-0073-2

Manikam, N.R., Pantoro, N.I., Komala, K., \& Sari, A.D. (2018). Comparing the Efficacy of Ketogenic Diet with Low-Fat Diet for Weight Loss in Obesity Patients: Evidenc-Based Case Report. World Nutrition Journal, 2(1), 7. doi: $.25220 / \mathrm{wnj} / \mathrm{v} 02.11 .0002$

Mansoor, N., Vinknes, K.J., Veierod, M.B., \& Retterstol, K. (2016). Effects of lowcarbohydrate diets v. low-fat diets on body weight and cardiovascular risk factors a metaanalysis of randomised controlled trials. British Journal of Nutrition, 115(3), 466-479. doi: $.1017 / \mathrm{S} 0007114515004699$

Masood, W., \& Uppaluri, K. (2019). Ketogenic Diet. Retrieved from https://www.ncbi.nlm. nih.gov/books/NBK499830/

McDougall, A., Bayley, M., \& Munce, S.E.P. (2018). The ketogenic diet as a treatment for traumatic brain injury: a scoping review. Brain Injury, 32(4), 416-422. doi: 10.1080/02699052.2018.1429025

Meira, D.A.I., Romão, T.T., Do Prado, H.J.P., Krüger, L.T., Pires, M.E.P., \& Da Conceição, P.O. (2019). Ketogenic diet and epilepsy: What we know so far. Frontiers in Neuroscience,
13(JAN), 1-8. https://doi.org/10.3389/ fnins.2019.00005

Mohorko, N., Černelič-Bizjak, M., PoklarVatovec, T., Grom, G., Kenig, S., Petelin, A., \& Jenko-Pražnikar, Z. (2019). Weight loss, improved physical performance, cognitive function, eating behavior, and metabolic profile in a 12 -week ketogenic diet in obese adults. Nutrition Research, 62, 64-77. doi: 10.1016/j. nutres.2018.11.007

Oh, R., \& Uppaluri, K.R. (2019). Low Carbohydrate Diet. diakses dari https://www.ncbi.nlm.nih. gov/books/NBK537084/

Paoli, A. (2014). Ketogenic diet for obesity: Friend or foe? International Journal of Environmental Research and Public Health, 11(2), 2092-2107. doi: 10.3390/ijerph110202092

Pinto, A., Bonucci, A., Maggi, E., Corsi, M., \& Businaro, R. (2018). Anti-oxidant and antiinflammatory activity of ketogenic diet: New perspectives for neuroprotection in alzheimer's disease. Antioxidants, 7(5). doi: 10.3390/ antiox 7050063

Puchalska, P., \& Crawford, P.A. (2017). Multidimensional Roles of Ketone Bodies in Fuel Metabolism, Signaling, and Therapeutics. Cell Metabolism, 25(2), 262-284. doi: 10.1016/j. cmet.2016.12.022

Qi, X., \& Tester, R.F. (2019). The 'epileptic diet'- ketogenic and/or slow release of glucose intervention: A review. Clinical Nutrition, (Article in Press). doi: 10.1016/j. clnu.2019.05.026

Roehl, K., \& Sewak, S.L. (2017). Practice Paper of the Academy of Nutrition and Dietetics: Classic and Modified Ketogenic Diets for Treatment of Epilepsy. Journal of the Academy of Nutrition and Dietetics, 117(8), 1279-1292. doi: 10.1016/j.jand.2017.06.006

Rusek, M., Pluta, R., Ułamek-kozioł, M., \& Czuczwar, S.J. (2019). Ketogenic Diet in Alzheimer' s Disease, 1-19.

Seidelmann, S.B., Claggett, B., Cheng, S., Henglin, M., Shah, A., Steffen, L.M., ... Solomon, S.D. (2018). Dietary carbohydrate intake and mortality: a prospective cohort study and metaanalysis. The Lancet Public Health, 3(9), e419e428. doi: 10.1016/S2468-2667(18)30135-X

Sumithran, P., \& Proietto, J. (2008). Ketogenic diets for weight loss: A review of their principles, safety and efficacy. Obesity Research and Clinical Practice, 2(1), 1-13. https://doi. org/10.1016/j.orcp.2007.11.00 
Vargas, S., Romance, R., Petro, J. L., Bonilla, D. A., Galancho, I., Espinar, S., Kreider, R.B., BenitezPorres, J. (2018). Efficacy of Ketogenic Diet on Body Composition During Resistance Training in Trained Men : A Randomized Controlled Trial. Journal of the International Society of Sports Nutrition (2018) 15:31. doi: 10.1186/ s12970-018-0236-9
Weber, D.D., Aminzadeh-Gohari, S., Tulipan, J., Catalano, L., Feichtinger, R.G., \& Kofler, B. (2019). Ketogenic diet in the treatment of cancer - Where do we stand? Molecular Metabolism, (xxxx). doi: 10.1016/j.molmet.2019.06.026

WHO (2016). "Prevalence of Obesity among Adults, BMI $\geq 30$, Age-Standardized Estimates by World Bank Income Group." 2016. Retrieved from http://apps.who.int/gho/data/view.main. WB2480A?lang=en. 